\title{
Team planning under an electricity failure for a GSM operator
}

\section{Bir GSM operatörü için elektrik kesintisi durumunda ekip planlanma}

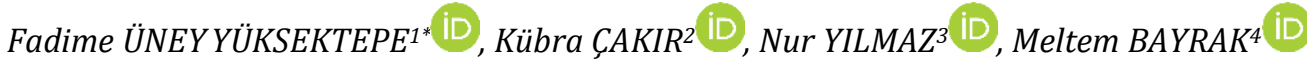

1,2,3,4 Department of Industrial Engineering, Faculty of Engineering, İstanbul Kültür University, İstanbul, Turkey. f.yuksektepe@iku.edu.tr, kubracakir26@gmail.com,nuryilmaz94@gmail.com, meltembayrak94@gmail.com

\begin{abstract}
Base stations are very important for all GSM operators. Efficient base stations prevent income loss while bringing prestige to the company. This study deals with the problem of transportation planning of portable generators during electricity failure for a leading Turkish GSM operator. There are often electricity failures in a particular area of Mersin which cause not only customer complaints but also income loss for the company. After an electricity failure, a battery steps in for that station. However, the lifetime of battery is limited and sometimes not enough during the failure. In that case, a fixed generator could step in to give service properly. Unfortunately, because of the high cost of fixed generators, not all base stations have a fixed generator. Therefore, the company tries to interfere this problem by using limited number of portable generators. Field operation teams transport and set up these portable generators to the sites with electricity failure before the battery dies. The problem is to schedule the transportation of portable generators to the base stations with electricity failure. In this study, composite dispatching rule, one of the scheduling algorithms, is used to solve this planning problem effectively. An Excel based decision support system has been developed for field operation team. Whenever a failure occurs, after inputting necessary information to the Excel, transportation schedule for each team could be easily obtained by the company experts.
\end{abstract}

Keywords: Scheduling, Telecommunication, Team planning

\section{Introduction}

Along with the technological improvements in the telecommunication, mobile services grow rapidly and high number of base stations has been installed to increase service quality and coverage. For a telecommunication company, maintenance planning of the base stations becomes very challenging. Especially, in the case of electricity failure, each minute is critical and efficient backup should be provided.

In this study, team-planning problem of a leading Turkish GSM operator is investigated for a specific region. In Mersin, electricity failures have been seen very frequently. After electricity failures, battery steps in for a base station, however life of battery is short. Due to high purchasing cost, all base stations don't have the generator. Therefore, limited numbers of portable generators have to be carried to the base stations where electricity failure occurred. To transport and set up the portable generators, the company has a fixed number of field operation teams. These teams should transport the portable generators to base station where its battery is about to run out. Planning the transportation efficiently in order to solve the

\section{$\mathbf{O z}$}

Tüm telekomünikasyon operatörleri için baz istasyonları önemli bir yer teşkil etmektedir. Verimli çalışan baz istasyonları gelir kaybının önüne geçmekte olup şirkete prestij kazandırmaktadır. Bu çalışma, Türkiye'nin önde gelen GSM operatörlerinden birinin elektrik kesintisi durumunda taşınabilir jenaratörlerin baz istasyonlarına dağıtımının planlaması ile ilgilenmektedir. Mersin'in belirli bir bölgesinde sık sık meydana gelen elektrik kesintileri müşteri şikayetlerinin yanı sıra firma için gelir kaybına neden olmaktadır. Elektrik kesintisi yaşandıktan sonra, o baz istasyonu için akü devreye girmektedir. Fakat akünün ömrü fazla uzun değildir ve bazen kesinti süresince yeterli olmamaktadır. Akü bittikten sonra baz istasyonunun çalıșabilmesi için sabit jeneratörün devreye girmesi beklenmektedir. Öte yandan, sabit jeneratörlerin maliyetleri yüksek olduğundan her baz istasyonu bu jeneratöre sahip değildir. Bu nedenle firma sınırl sayıdaki tașınabilir jeneratörleri kullanarak duruma müdahale etmeye çalıșaktadır. Bölge operasyon takımları, elektrik kesintisi olduğunda kesintiden etkilenen baz istasyonlarına akünün bitmesinden önce taşınabilir jeneratörleri ulaștırmalı ve kurulumu yapmalıdır. Ele alınan problem, tașınabilir jeneratörleri elektrik kesintinin olduğu baz istasyonlarına dağıtımının çizelgelenmesidir. Bu çalıșmada önerilen problemi etkin bir șekilde çözmek için 'Bileșik Dağıtım Kuralı' adı verilen çizelgeleme algoritması uygulanmıștır. Bölge operasyon ekibi için en uygun planı gösteren bir Excel tabanl karar destek sistemi geliștirilmiștir. Kesinti ne zaman yaşanırsa, gerekli bilgiler Excel'e girildikten sonra, şirket uzmanları tarafından her takım için dağıtım çizelgesi kolaylıkla elde edilebilecektir.

Anahtar kelimeler: Çizelgeleme, Telekomünikasyon, Ekip planlama problem in a short amount of time is needed. Life of battery, whether fixed generator exists or not, situation of the electricity failure and importance of the base station are among the important parameters needed to solve the planning efficiently.

In this study, composite dispatching rule, one of the scheduling algorithms, is applied to solve the proposed problem efficiently. The purpose is to maximize the total utilization of the resources and the total number of scheduled activities. In this problem, the resources on hand are the field operation teams whereas activities are the transportation of the portable generators. As the number of portable generators and field operation teams are fixed, aim is try to transport as much as portable generators to the base stations. Each base station has a different role in the network, as the number of customers they are serving is different. Hence, each of them has a distinct weight to represent their importance. The critical ones have a higher priority while solving the problem.

The proposed algorithm is implemented in Excel. For different input data, plan for the field operation team could be obtained by the help of the developed Excel based decision support system. As the company is not using an analytical approach, the 
proposed user-friendly tool will help the company to make an efficient plan in the case of electricity failure.

The paper starts with the literature review. Section 2 represents the problem definition in detail. Section 3 describes the methodology. Implementation and results are given in Section 4 by showing the input data and obtained the results. Moreover, screenshots of Excel based decision support tool is also provided. Section 5 gives the conclusion of the study.

\subsection{Literature review}

Base stations represent the main contributor to give service properly for all GSM operators. If the service is given properly, customers become loyal. These loyal customers ready to pay more and recommend to other people [1].

In recent years, some researches about base station performance have been studied in Turkey in Karadeniz Technical University. To identify the performance of mobile base stations, many parameters and equations related to the base station and mobile base station communication system have been presented from many domestic and foreign sources. The characteristics of parameters have been created in the appropriate program environment in order to visualize them. While these characteristics are calculated, calculations have been applied in different parameters that have not been processed through only one parameter. Obtained characteristics are interpreted and transformed into the practice. Ensuring the people to communicate without interruption has been seen as the purpose. It has been tried to provide people with as little radiation as possible in weather conditions where communication is affected in various environmental conditions [2].

Service quality is very important issue for GSM operators, because it affects the customer satisfaction provided. There are many GSM operators and customers can change their current operator easily. Customers expect to get maximum quality from services that they paid for. A research in Nigeria [3] indicates that there are three main factors which are accessibility, maintainability and connection quality (voice quality) that effects the performance of service. Poor performance causes customer complaints. Besides, service failures cannot be accepted by customers in terms of satisfaction. Suggested methods of improvement part of this study remarks that government should resolve frequentative electricity failures. This is solution for dependence on generators to provide power.

The performance of the base stations and also other topics are discussed in literature. Such as in another study that has been written in Simon Fraser University with the aid of University of Mississippi by using one of the China's GSM company's data, due to the growth use of mobile phones with $3 \mathrm{G} / 4 \mathrm{G}$ cellular networks and emerging $5 \mathrm{G}$, supporting the mobile base stations have been argued. It is possible to see that even in rural areas of the China, base stations are being used. However due to many reasons, base stations could not work properly in rural and even in metropolitan areas where even has this problem less frequently. Therefore, upholding of base stations in a power outage situation has become an issue. This situation creates an awareness to emphasize how important to have a backup system in company's base stations or how important the power of the backup system. A backup system gives companies more than just one advantage which one of them is sustainable service. An analysis has been made for this issue with the data that are collected from the base stations of China Mobile Ltd co. which has backup battery group to improve their service availability. Formulated model used the parameters of battery voltage and lifetime to help the backup batteries work more efficiently. Their solution has made a progress in cellular network with $18.09 \%$ [4].

Also some studies in different perspective have been applied. Related to base station traffic load and power consumption, linear power consumption model has been developed. Measurements of base station power consumption under real traffic loads have been calculated. Working and weekend days or daytime and night time have an effect on traffic load [5]. When traffic load is high, micro base stations influence power consumptions of the network [6]. Micro base stations reduce the consumption of energy for a mobile network [7].

From the perspective of workforce scheduling and routing, there exist many studies in literature as summarized by Castillo-Salazer et al. [8]. In those problems, workers are performing the activities that exist in different locations. Cheng and Rich [9] studied visits of nurses to patient homes whereas Cordeau et al. [10] planned technicians visits for repairs and installations. In those problems, as the number of activities is higher than the workforce, more than one activity should be performed by visiting them one and other. Thus, a routing problem should be studied. Main characteristics of these problems are listed as time windows, mode of transportation, start and end locations, skills and qualification of workers, service time, teaming and connected activities [8]. Depending on the characteristics, problems could be harder. In order to solve this types of workforce scheduling and routing problems, generally complex mathematical models (mixed integer programming, integer linear programming and constraint programming) are proposed like the one proposed by CastilloSalazer et al. [8]. Therefore, solution time increases as the number of activities increases. Hence, for a real life application, it is not preferable to obtain the solution of the problem in more than one hour.

As mentioned above, there are many studies about base stations, but there is no study which includes base stations' service failures because of the generator deficiency and portable generator transportation plan to solve that problem. There exist some studies on workforce scheduling and routing in literature. However, the problem characteristics are not the same as in this study. In this study, each worker has the same level of skill and service times are constant. Furthermore, team members are not changing and they are using vehicles to transport. On the other hand, the activities have some release times and due dates. The details of the problem are given in the next section.

\section{Problem definition}

In different regions of Mersin, long and frequent electricity failures have been occurred at the same time. During electricity failures, battery steps in for each base station, however life of battery is short. After the battery runs out, fixed generator starts to work automatically if there is any in the base station. Unfortunately, all base stations do not have an installed fixed generator because of high purchasing costs. Therefore, the company is using portable generators to manage this issue. However, the number of portable generators is limited. Hence, field operating teams should transport these portable generators to the base station where its battery is about to run out. 
Figure 1 shows a representative example of the problem network. Blue base stations represent properly working base station. However, red base stations represent the ones those are not working due to electricity failure. If the failure is in working hours, the technicians should go from main warehouse to the base station. However, if the failure is in nonworking hours, the technician whose house is closer to the failure area will go to the base station.

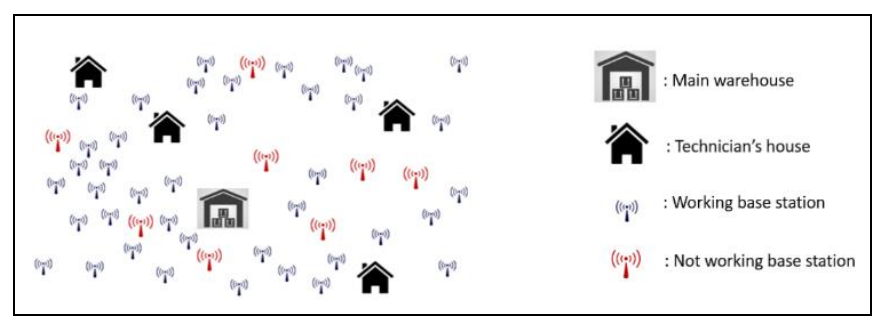

Figure 1: Schematic representation of the problem.

The problem is carrying limited number of portable generators to the areas where electricity failure exists by the help of two field operation teams. While solving this problem, life of battery, fixed generator existence, situation of the electricity failure, importance, location of the base station, number of available portable generators, technicians and their locations and location of the main depot are used for the input data. Life of battery decreases in time as expected. Hence, some of the batteries can supply for 12 hours, some of them for 6 hours and others for 2 hours. Due to their high costs, all base stations do not have a fixed generator. Furthermore, electricity failure does not exist in all base station and exactly which base stations have the problem is known. Importance of the base station depends on traffic load in terms of voice and data load. The base stations with a higher traffic load will have high importance. Location of the base station is going to be defined by longitude and latitude. Distances between main warehouse, base stations with electricity failure and technicians' houses are calculated by considering their longitudes and latitudes. Purpose of this study is planning the transportation efficiently in order to solve the problem in a short amount of time.

\section{Methodology}

In this section, proposed methodology is explained in detail and the followed steps of the methodology are shown in Figure 2.

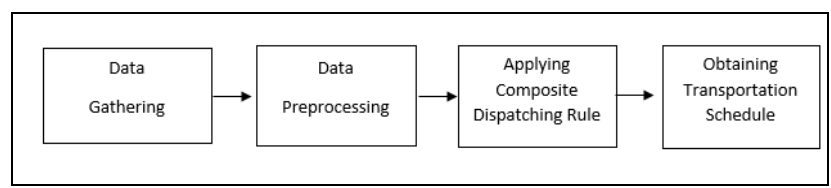

Figure 2: Schematic representation of the problem.

The following assumptions are used in the methodology:

- Voice and data traffic load affects the importance of base stations with equal weights,

- Total installation and transportation time for each base station is 1 hour,

- Total distances between the locations are calculated by using longitude and latitude values,

- Planning period is assumed as 24 hours,

- $\quad$ Starting of the electricity failure is assumed as time 0 .

\subsection{Data gathering and preprocessing}

Data obtained from the company is represented with the following notations:

$\begin{array}{ccl}i & : & \text { Base transceiver station (BTS) } \\ L o_{i} & : & \text { Longitude of base station } i, \\ L a_{i} & : & \text { Latitude of base station } i, \\ V T L_{i} & : & \text { Voice traffic load on base station } i \text { (Erlang), } \\ D T L_{i} & : & \text { Data traffic load on base station } i \text { (GByte), } \\ B L_{i} & : & \text { battery life of base station } i \text { (h), } \\ F G E_{i} & : & 1 \text { if fixed generator exists on base station } i, 0 \\ & & \text { otherwise, } \\ E F_{i} & : & 1 \text { if electricity failure exists in base station } i, 0 \\ & & \text { otherwise, } \\ W H & : & 1 \text { if electricity failure starts during working hours, } \\ & & \text { o otherwise, } \\ E F T_{i} & : & \text { estimated failure time for base station } \mathrm{i}, \\ M D L o & : & \text { longitude of main depot, } \\ M D L a & : & \text { latitude of main depot, } \\ F O T 1 L o & : & \text { longitude of field operation team 1, } \\ F O T 1 L a & : & \text { latitude of field operation team } 1, \\ F O T 2 L o & : & \text { longitude of field operation team 2, } \\ F O T 2 L a & : & \text { latitude of field operation team 2. }\end{array}$

The parameters defined above have to be converted to the parameters that are suitable for composite dispatching rule. Portable generator transportation and installation is the jobs to be processed. Furthermore, field operation teams will be the machines that will perform the jobs. For each job, weight, release time, due date, processing time and machine availabilities are necessary for the scheduling algorithm.

First step is to calculate the weight of each base station by using data traffic load and voice traffic load. If a base station has a higher data and voice traffic load, it will have a higher weight. After normalization of voice and traffic load, equal importance is given to calculate the weight in the range 0 to 100 . Hence, Equation 1 is used to calculate the weight of each base station.

$$
=\frac{w_{i}}{\max _{i}\left\{V T L_{i}\right\}-\min _{i}\left\{V T L_{i}\right\}}+\frac{50 \cdot\left(D T L_{i} \cdot \min _{i}\left\{D T L_{i}\right\}\right)}{\max _{i}\left\{D T L_{i}\right\}-\min _{i}\left\{D T L_{i}\right\}}
$$

Release time is calculated by using Equation 2. At the start of electricity failure, time is assumed as 0 . Then, if electricity failure exists, release time is 0 . Otherwise, 24 , a very big value, is given for that base station. As the planning horizon is shorter, the base station with a high release time will not be considered for planning.

$$
r_{i}=\left\{\begin{array}{cc}
0 & \text { if } E F_{i} \text { equals to } 1 \\
24 & \text { otherwise }
\end{array}\right.
$$

Due date is obtained based on battery life, electricity failure, fixed generator existence. If an electricity failure exists and the base station does not have any fixed generator, due date equals to battery life. If base station has fixed generator, then 2 more hours is added to the battery life to calculate the due date. However, if there is no electricity failure, 24 hours are assigned to due date. Equation 3 gives these conditions for due date.

$$
d_{i}=\left\{\begin{array}{cc}
B L_{i} & \text { if } E F_{i}=1 \text { and } F G E_{i}=0 \\
B L_{i}+2 & \text { if } E F_{i}=1 \text { and } F G E_{i}=1 \\
24 & \text { if } E F_{i}=0
\end{array}\right.
$$

After talking with company managers, processing time $\left(p_{i}\right)$ is assumed as 1 hour for all operations. As time required for 
transportation and installation will be approximately 1 hour, this is an acceptable assumption.

With the help of longitude and latitude points, distance $(\mathrm{km})$ to field operation team 1 and field operation team 2 is obtained by using Equation 4 and Equation 5, respectively.

$$
\begin{aligned}
& \operatorname{dFOT}_{i}=1.4 \cdot\left(\operatorname { a c o s } \left(\sin \left(L a_{i} \cdot \frac{\pi}{180}\right)\right.\right. \\
& \cdot \sin \left(F O T 1 L a_{i} \cdot \frac{\pi}{180}\right) \\
& +\cos \left(L a_{i} \cdot \frac{\pi}{180}\right) \\
& \cdot \cos \left(F O T 1 L a_{i} \cdot \frac{\pi}{180}\right) \\
& \left.\cdot \cos \left(L o_{i} \cdot \frac{\pi}{180}-{\text { FOT } 1 L o_{i}}_{1} \cdot \frac{\pi}{180}\right)\right) \\
& .6371) \\
& \operatorname{dFOT}_{i}=1.4 \cdot\left(\operatorname { a c o s } \left(\sin \left(L a_{i} \cdot \frac{\pi}{180}\right)\right.\right. \\
& \cdot \sin \left(F O T 2 L a_{i} \cdot \frac{\pi}{180}\right) \\
& +\cos \left(L a_{i} \cdot \frac{\pi}{180}\right) \\
& \cdot \cos \left(F O T 2 L a_{i} \cdot \frac{\pi}{180}\right) \\
& \left.\cdot \cos \left(L o_{i} \cdot \frac{\pi}{180}-{\text { FOT } 2 L o_{i}}_{1} \cdot \frac{\pi}{180}\right)\right) \\
& .6371)
\end{aligned}
$$

Closeness between field operation teams and base stations is used to calculate the machine availabilities. Availability of field operation team 1 and field operation team 2 is calculated by using Equation 6 and 7, respectively. If failure time is not a working hour and distance is greater than $15 \mathrm{~km}$, team is not available for that base station. Otherwise, if it is a working hour or distance is lower than $15 \mathrm{~km}$, both team will be available for that base station.

$$
\begin{aligned}
& \text { AFOT }_{\mathrm{i}}=\left\{\begin{array}{cc}
0 & \mathrm{WH}=0 \text { and dFOT } 1>15 \\
1 & \text { otherwise }
\end{array}\right. \\
& \text { AFOT }_{\mathrm{i}}=\left\{\begin{array}{cc}
0 & \mathrm{WH}=0 \text { and dFOT2 } \\
1 & \text { otherwise }
\end{array}\right.
\end{aligned}
$$

Machine availabilities depend on the parameters $A F O T 1_{i}$ and $A F O T 2_{i}$. If both parameters are $1, M_{i}$ will consist of M1 and M2. If $A F O T 1_{i}$ equals to 1 and $A F O T 2_{i}$ equals to $0, M_{i}$ will consist of only M1. If AFOT2 $2_{\mathrm{i}}$ equals to 1 and AFOT $1_{\mathrm{i}}$ equals to $0, M_{i}$ will consist of only M2. Otherwise, $M_{i}$ will be an empty set.

\subsection{Composite dispatching rule}

This section represents a formal definition and explanation of composite dispatching rule [11]. For a given time period, one of the resources (field operation teams) is supposed to be assigned to one activity (base station). Activity $i, i=$ $\{1,2, \ldots, n\}$ has a total of $n$ jobs.

$p_{i}$ is duration of activity $i$ and has to fit in a given time period that is determined by an earliest starting time $r_{i}$ and latest finishing time $d_{i}$. This reservation model allows using slack in a specific time period that means $p_{i}<d_{i}-r_{i}$ for each activity. Available resources of activity $i$ is represented by $M_{i} . w_{i}$ is the weight of base station in view of its importance. $I_{i}$ is priority index that is function of $w_{i} / p_{i}$ and $\left|M_{i}\right|$ for jobs. The notations that are used in the algorithm are summarized as follows:

$p_{i} \quad$ : Duration of activity $i$,

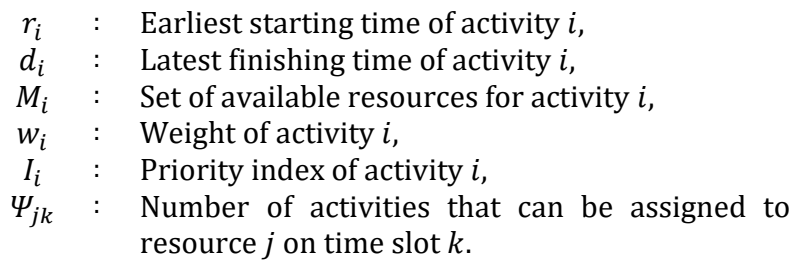

Priority index, $I_{i}$, represents the flexibilities of activities. It is calculated by using Equation 8 . While $w_{i} / p_{i}$ is high and $M_{i}$ is small, then a lower index will be obtained. As $M_{i}$ is a set, $\left|M_{i}\right|$ represents the cardinality of this set. The activities need to be ordered in ascending order of $I_{i}$ that means least flexible activities should have a higher importance when planning [12].

$$
\mathrm{I}_{\mathrm{i}}=\frac{\left|\mathrm{M}_{\mathrm{i}}\right|}{\mathrm{W}_{\mathrm{i}} / \mathrm{p}_{\mathrm{i}}}
$$

$\psi_{j k}$ represents the number of jobs that can be processed on resource $j$ in the time slot $k$ which is represented by $[k-1, k]$. The higher this number is, the more flexible resource $j$ is in this time slot $k$. If the activity needs a resource in the time period $\left[k, k+p_{i}\right]$, then the choice of resource $j$ depends on function of the factors $\psi_{j, k+1}, \ldots, \psi_{j+k+p_{i}}$. This function is given in Equation 9.

$$
g\left(\psi_{j, k+1}, \ldots, \psi_{j, k+p_{i}}\right)=\left(\sum_{l=1}^{l=p_{i}} \psi_{j, k+1}\right) / p_{i}
$$

This heuristic is summarized as follows:

Step 0 : Calculate priority indices for activities and resources. Order activities according to priority index $\left(I_{j}\right)$ from lowest to highest,

Step 1 : Set $i=1$,

Step 2 : For activity $i$, select the machine and time slot with lowest rank by using calculated $\Psi_{j k}$ values. Discard job $i$, if it cannot be processed at all,

Step 3 : If $i=n$ STOP; otherwise set $i=i+1$ and go back to Step 2.

Algorithm is used for the activities with $d_{i}$ not equal to 24 in order to list the base stations to be visited. The difference on the algorithm when obtaining the transportation schedule is the stopping criterion. As the number of portable generators is limited, algorithm will end when the number of activities processed is equal to the number of portable generators on hand. Therefore, the efficient transportation and installation schedule is obtained for the problem.

\subsection{Proposed mathematical model}

In order to compare the solution of the proposed approach, an integer programming model is developed for the given problem. In addition to the previous indices and parameters, additional definitions are needed for the mathematical model. In this model, $t$ and $t^{\prime}$ denotes the time periods. Moreover, $M$ is a very big number. The following decision variables are defined to formulate the model.

$$
\mathrm{X} 1_{\text {it }}
$$

$=\left\{\begin{array}{lc}0 & \text { if base station i will be visited in period t by FOT } 1 \\ 1 & \text { otherwise }\end{array}\right.$ 
$\mathrm{X} 2_{\text {it }}$

$=\left\{\begin{array}{lc}0 & \text { if base station i will be visited in period t by FOT2 } \\ 1 & \text { otherwise }\end{array}\right.$

The developed mathematical model is given below:

$$
\begin{aligned}
& \operatorname{Max} z=\sum_{i: d_{i} \neq 24} \sum_{t} w_{i} \cdot\left(X 1_{i t}+X 2_{i t}\right) \\
& X 1_{i t}+X 2_{i t} \leq 1 \quad \forall i, \forall t \\
& \sum_{i} X 1_{i t} \leq 1 \quad \forall t \\
& \sum_{i} X 2_{i t} \leq 1 \quad \forall t \\
& X 1_{i t} \leq \text { AFOT }_{i} \quad \forall i, \forall t \\
& X 2_{i t} \leq \text { AFOT }_{i} \quad \forall i, \forall t \\
& \sum_{i} \sum_{t}\left(X 1_{i t}+X 2_{i t}\right) \leq 10 \\
& r_{i} \leq t \cdot X 1_{i t}+M \cdot\left(1-\sum_{t^{\prime}} X 1_{i t \prime}\right) \quad \forall i, \forall t \\
& d_{i} \geq t \cdot X 1_{i t}-M \cdot\left(1-\sum_{t \prime} X 1_{i t \prime}\right) \quad \forall i, \forall t \\
& r_{i} \leq t \cdot X 2_{i t}+M \cdot\left(1-\sum_{t \prime} X 2_{i t \prime}\right) \quad \forall i, \forall t \\
& d_{i} \geq t \cdot X 1_{i t}-M \cdot\left(1-\sum_{t^{\prime}} X 1_{i t \prime}\right) \quad \forall i, \forall t \\
& X 1_{i t}, X 2_{i t} \in\{0,1\} \quad \forall i, \forall t
\end{aligned}
$$

Objective function given in Equation 12 maximizes the weighted number of assigned base stations which needs a portable generator. A base station can be visited by either field operation team 1 or field operation team 2 as given in Equation 12. For a given time period, field operation teams cannot be assigned to more than one base stations. This restriction is represented by Equation 14 and Equation 15, respectively for each team. Equation 16 and Equation 17 ensures that if field operation team is not available for a base station, it cannot be assigned to it. Equation 10 states that total number of assignments should be at most 10 (the number of portable generators). In order to visit the base station in between release time and due date for each base station for each team, Equation 19, Equation 20, Equation 21 and Equation 22 is defined. Finally, Equation 23 shows that decision variables are binary.

\section{Implementation and results}

In this section, the data obtained from the company, explanation and application of the suggested methodology are investigated in detail.

\subsection{Input data}

In the region that this study focused on, there exist 85 base stations. Real data of these base stations are obtained from company and are shown in Table 1 . As it can be seen from Table 1, electricity failure affects some of the base stations, not all of them. As this case is obtained from a past electricity failure, this situation may change from one case to another.

In the company, operation teams work from 8:00 to 17:00. If electricity failure is within working hours, operation teams depart from main depot. If failure is out of working hours, they depart from their houses.

Table 2 shows location of field operation team 1 , field operation team 2 and main depot. For example, for team 2 longitude is 3.038026 and latitude is 43.32965 . Locations of all base stations, main depot, houses of field operation teams could be seen from the Google Earth view in Figure 3.

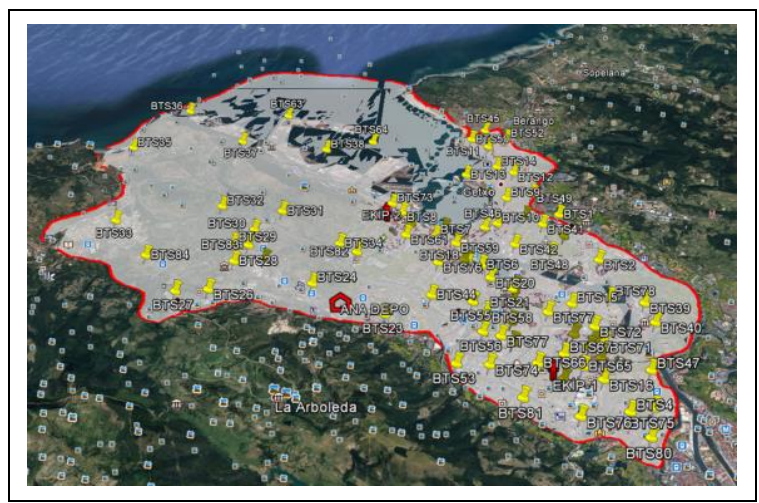

Figure 3: Representation of the locations.

\subsection{Results}

Preprocessing equations are applied to the input data. The obtained data from implemented transactions are shown in Table 3. For each base station, weight, release time, due date, processing time, distances to field operation teams' houses and team availabilities are calculated.

Base stations, where portable generators should be transported, are listed in Excel by a pivot table. This list is arranged in ascending order according to $I_{i}$ which represents their flexibility level.

Company has 10 portable generators, that's why the first 10 values in the table are used to assign portable generators to base stations. According to greatness of weights, most important base station is obtained from the list. After selecting the base station, availability of each FOT for each time slot is calculated as shown in Figure 4. After obtaining the availabilities of each base station, overall availabilities are automatically calculated as given in Figure 5. Algorithm finds the minimum value in all time slots for FOT1 and FOT2. After selecting FOT1, algorithm checks minimum value. Base station is assigned to the first minimum value as given in Figure 6. After assigning the first important base station to one of the FOTs, new sheet is opened for the second important base station. Similar calculations are performed for the second one. Other remaining eight base stations are assigned by using the same process.

All assignments are obtained as given in Figure 7. Obtained transportation schedule in Figure 7 is for a given instant electricity failure. Base station 72 , base station 15 , base station 16 , base station 37 , base station 21 and base station 23 are assigned to field operation team 1 . On the other hand, base station 66 , base station 71 , base station 22 and base station 24 are planned for field operation team 2 . 
Table 1: Data collected.

\begin{tabular}{|c|c|c|c|c|c|c|c|c|c|}
\hline BTS & $L o_{i}$ & $L a_{i}$ & $\begin{array}{c}V T L_{i} \\
\text { (Erlang) }\end{array}$ & $\begin{array}{c}D T L_{i} \\
\text { (GByte) }\end{array}$ & $\begin{array}{l}B L_{i} \\
(\mathrm{~h})\end{array}$ & $F G E_{i}$ & $E F_{i}$ & $E F T_{i}$ & $W H$ \\
\hline 1 & -2.994 & 43.328 & 184 & 168 & 2 & 0 & 0 & - & 0 \\
\hline 2 & -2.985 & 43.316 & 321 & 151 & 2 & 0 & 0 & - & 0 \\
\hline 3 & -2.993 & 43.299 & 675 & 237 & 2 & 0 & 0 & - & 0 \\
\hline . & . & ${ }^{\circ}$ & . & . & . & . & . & . & . \\
\hline . & . & . & . & . & . & . & . & . & . \\
\hline 43 & -3.003 & 43.328 & 2021 & 965 & 12 & 0 & 1 & 8 & 0 \\
\hline 44 & -3.026 & 43.308 & 682 & 175 & 6 & 0 & 1 & 4 & 0 \\
\hline . & . & $\cdot$ & . & . & . & . & . & . & . \\
\hline . & . & . & . & . & . & . & . & . & . \\
\hline 84 & -3.072 & 43.319 & 378 & 423 & 2 & 0 & 0 & - & 0 \\
\hline 85 & -3.096 & 43.317 & 1344 & 503 & 6 & 0 & 0 & - & 0 \\
\hline
\end{tabular}

Table 2: Location of teams and main depot.

\begin{tabular}{ccc}
\hline & Longitude & Latitude \\
\hline Main Depot & -3.046083 & 43.30542 \\
FOT1 & -2.997447 & 43.2918 \\
FOT2 & -3.038026 & 43.32965 \\
\hline
\end{tabular}

Table 3: Data after preprocessing.

\begin{tabular}{|c|c|c|c|c|c|c|c|c|}
\hline $\begin{array}{c}\text { Base } \\
\text { Station }\end{array}$ & $w_{i}$ & $\begin{array}{c}r_{i} \\
(\mathrm{~h})\end{array}$ & $\begin{array}{c}d_{i} \\
(\mathrm{~h})\end{array}$ & $\begin{array}{l}p_{i} \\
\text { (h) }\end{array}$ & $d F O T 1_{i}(\mathrm{~km})$ & $A F O T 1_{i}$ & $d F O T 2_{i}(\mathrm{~km})$ & ${ }_{A F O T} 2_{i}$ \\
\hline 1 & 10.48 & 24 & 24 & 1 & 5.72 & 1 & 5.01 & 1 \\
\hline 2 & 11.90 & 24 & 24 & 1 & 4.08 & 1 & 6.35 & 1 \\
\hline 3 & 22.39 & 24 & 24 & 1 & 1.23 & 1 & 7.02 & 1 \\
\hline . & $\cdot$ & . & . & . & . & . & . & . \\
\hline . & $\cdot$ & · & $\cdot$ & $\cdot$ & $\cdot$ & $\cdot$ & $\cdot$ & $\cdot$ \\
\hline . & . & . & . & . & . & . & . & . \\
\hline 43 & 83.42 & 0 & 24 & 1 & 5.67 & 1 & 4.02 & 1 \\
\hline 44 & 19.24 & 0 & 24 & 1 & 4.05 & 1 & 3.68 & 1 \\
\hline . & $\cdot$ & . & . & . & . & . & . & . \\
\hline . & . & . & · & · & $\cdot$ & . & . & $\cdot$ \\
\hline . & . & . & . & . & . & . & . & . \\
\hline 84 & 27.19 & 24 & 24 & 1 & 9.43 & 1 & 4.13 & 1 \\
\hline 85 & 47.68 & 24 & 24 & 1 & 11.88 & 1 & 6.90 & 1 \\
\hline
\end{tabular}

\begin{tabular}{|c|c|c|c|c|c|c|c|c|}
\hline \multicolumn{2}{|c|}{ B5 } & $\times \checkmark$ & $f_{\boldsymbol{x}}$ & \multicolumn{5}{|c|}{$=I F(A N D(\$ F \$ 2=1, B 4-1>=\$ B \$ 2, B 4<=\$ C \$ 2), 1,0)$} \\
\hline 4 & A & $\mathrm{B}$ & C & $\mathrm{D}$ & $\mathrm{E}$ & $\mathrm{F}$ & G & $\mathrm{H}$ \\
\hline 1 & Base Station & Release Time & Due Date & Processing Time (h) & Weight & Field Operation Team 1 & Field Operation Team 2 & Ij \\
\hline 2 & 16 & \begin{tabular}{|l|}
0 \\
\end{tabular} & 6 & \begin{tabular}{|l|}
1 \\
\end{tabular} & 66.3428 & 1 & \begin{tabular}{|c|}
1 \\
\end{tabular} & 0.030146 \\
\hline \multicolumn{9}{|l|}{3} \\
\hline 4 & BTS16 & 1 & 2 & 3 & 4 & 5 & 6 & 7 \\
\hline 5 & FOT1 & 1 & 1 & 1 & 1 & 1 & 1 & 0 \\
\hline 6 & FOT2 & 1 & 1 & 1 & 1 & 1 & 1 & 0 \\
\hline
\end{tabular}

Figure 4: Availability of FOT1 and FOT2 for BS16.

\begin{tabular}{|c|c|c|c|c|c|c|c|c|}
\hline \multicolumn{2}{|c|}{ B10 } & $\times \checkmark$ & $f_{\mathbf{x}}$ & \multicolumn{5}{|c|}{ 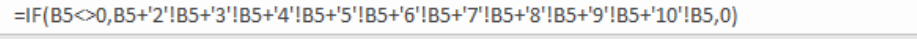 } \\
\hline 4 & A & B & c & D & E & $\mathrm{F}$ & G & $\mathrm{H}$ \\
\hline 1 & Base Station & Release Time & Due Date & Processing Time (h) & Weight & Field Operation Team 1 & Field Operation Team 2 & Ij \\
\hline 2 & 16 & 0 & 6 & 1 & 66.3428 & 1 & 1 & 0.030146 \\
\hline \multicolumn{9}{|l|}{3} \\
\hline 4 & BTS16 & 1 & 2 & 3 & 4 & 5 & 6 & 7 \\
\hline 5 & FOT1 & 1 & 1 & 1 & 1 & 1 & 1 & 0 \\
\hline 6 & FOT2 & 1 & 1 & 1 & 1 & 1 & 1 & 0 \\
\hline \multicolumn{9}{|l|}{7} \\
\hline 8 & & & & & & & & \\
\hline 9 & OVERALL & 1 & 2 & 3 & 4 & 5 & 6 & 7 \\
\hline 10 & FOT1 & 10 & 10 & 6 & 6 & 6 & 6 & 0 \\
\hline 11 & FOT2 & 10 & 10 & 6 & 6 & 6 & 6 & 0 \\
\hline
\end{tabular}

Figure 5: Overall availability of FOT1 and FOT2. 


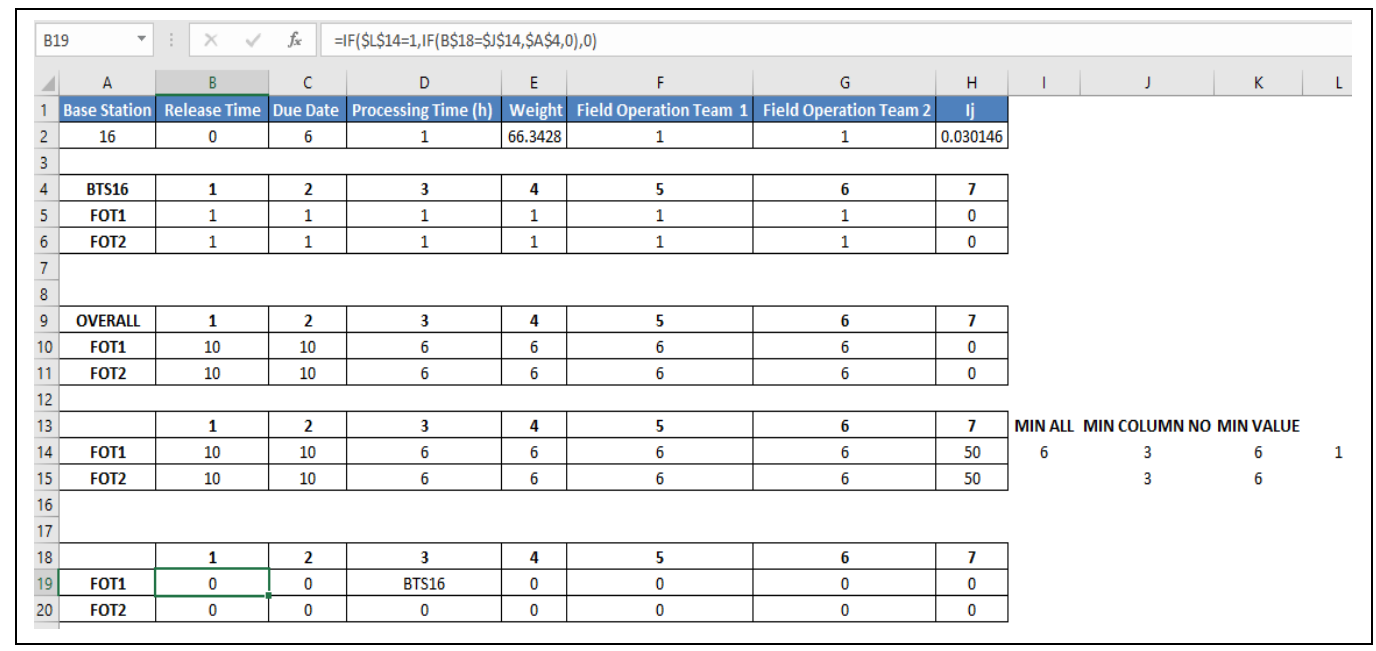

Figure 6: Assignment of the base station to FOT1.

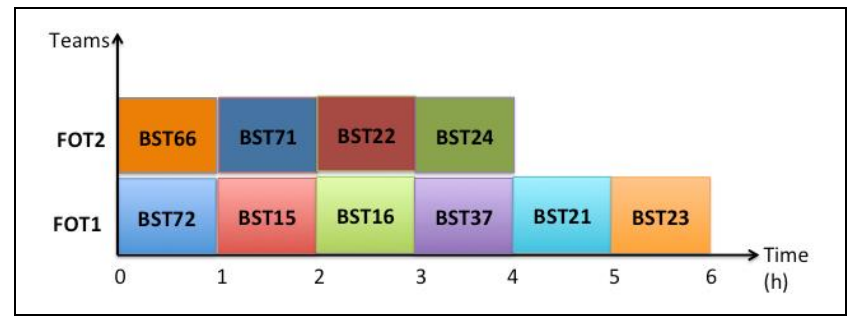

Figure 7: Overall assignments.

Moreover, the data is also prepared to run the proposed mathematical model. For the same data set, the optimal solution is obtained by using GAMS software and CPLEX solver. In the optimal solution, objective function value is 471,74 . When the optimal values of decision variables are converted to a Gantt chart, exactly the same solution given in Figure 7 is achieved. Therefore, both the mathematical model and the composite dispatching rule finds the same solution. As the GAMS software and CPLEX solver will require a costly investment for the company, the proposed composite dispatching rule is the better alternative to be applied in the real life.

In conclusion, an Excel based decision support tool is developed by using the composite dispatching rule approach. Planning engineers will only input the data as in Table 4. Each time, the "Electricity Failure", "Estimated Failure Time (h)" and Starting time of Electricty Failure:" values should be updated. When user enters new information related to the electricity failure, Excel changes all tables and does the new plan automatically as shown in Figure 4-7. Company could access to the planning results in a few seconds. Moreover, since there is no other analytical tool for this problem, company experts will get efficient results through this tool.

\section{Conclusion}

Nowadays, mobile services grow fast as a result of technological improvements in the telecommunication sector. High number of base stations has been set up to increase service quality and coverage. However, maintenance planning of the base stations for a telecommunication company is very difficult. Therefore, base stations play a significant role in order to give service properly.
In this study, transportation planning problem of portable generators in the case of electricity failure is handled for a leading Turkish GSM operator. In a specific region of Mersin, electricity failures have been seen frequently which cause revenue loss and reduction of prestige for the company. When the electricity failure happened, a battery steps in for that base station. Nevertheless, battery lifetime is limited and occasionally not enough during the failure duration. In this instance, a fixed generator could step in for service sustainability. But, due to high cost of fixed generator, all base stations do not have a fixed generator. For this reason, the company uses limited number of portable generators. Before the battery dies, field operation teams should transport and set up these portable generators to the base stations where electricity failure occurred. Consequently, the problem is to schedule the transportation of portable generators to these base stations. Within the planning problem, the base stations with a higher data and voice traffic load should be prioritized.

In this study, scheduling algorithm named composite dispatching rule is used with necessary parameters to solve this planning problem effectively. Moreover, an integer programming model is developed to compare these two methodologies. As two approaches give the same result, composite dispatching rule is selected to be applied in real life due to its simplicity and applicability. The steps and calculations of this algorithm are prepared in Excel. The efficient transportation schedule for a given instant electricity failure is obtained with this Excel based decision support system easily.

As it is mentioned, the user-friendly tool that is proposed in this study provides to get transportation schedule easily. When information of electricity existence, estimated failure time and starting time of electricity failure is entered to Excel by company experts, calculation tables are updated automatically. As a result of this, all plans could be obtained within a few seconds by planning engineers. It is hoped that this tool will be beneficial for the company which does not have any tool for solving this scheduling problem.

For future research, more data could be put to algorithm in order to enhance this study. Additional information about distances may be considered. Capacity of vehicle is three generators and teams may need to turn back to main depot for replenishment after they set these three generators. 
Table 4: Excel based decision support tool.

\begin{tabular}{|c|c|c|c|c|}
\hline Base Station & Electricity Failure & Estimated Failure Time (h) & Starting Time of Electricity Failure: & 04:00 \\
\hline 1 & 0 & - & & \\
\hline 2 & 0 & - & & \\
\hline 3 & 0 & - & & \\
\hline . & . & . & & \\
\hline . & . & . & & \\
\hline$\therefore$ & . & . & & \\
\hline 43 & 1 & 8 & & \\
\hline 44 & 1 & 8 & & \\
\hline . & . & . & & \\
\hline . & . & . & & \\
\hline . & . & . & & \\
\hline 84 & 0 & - & & \\
\hline 85 & 0 & - & & \\
\hline
\end{tabular}

Moreover, in real life the beginning time of electricity failure differs throughout the day. This study may be improved by considering these recommendations.

\section{Kaynaklar}

[1] Aydın S, Özer G. "The analysis of antecedents of customer loyalty in the Turkish mobile telecommunication market". European Journal of Marketing, 39(7/8), 910-925, 2005.

[2] Akbulut A. Mobile Base Station Performance Analysis. Msc Thesis, Karadeniz Teknik University, Trabzon, 2013.

[3] Adegoke AS, Babalola IT. "Quality of service analysis of GSM telephone system in Nigeria". American Journal of Scientific and Industrial Research, 2(5), 707-712, 2011.

[4] Fan X, Wang F, Liu J. "Boosting service availability for base stations of cellular networks by event-driven battery profiling". ACM SIGMETRICS Performance Evaluation Review, 44(2), 88-93, 2016.

[5] Lorincs J, Garma T, Petrovic G. "Measurements and modelling of base station power consumption under real traffic loads". Sensors, 12(4), 4181-4310, 2012.

[6] Richter F, Fehske AJ, Fettweis GP. "Energy efficiency aspects of base station deployment strategies for cellular networks". GLOBECOM Workshops, 2010 IEEE, Anchorage, 2010.
[7] Fehske AJ, Richter F, Fettweis GP. “Energy Efficiency Improvements through Micro Sites in Cellular Mobile Radio Networks". IEEE 2009 GLOBECOM Workshops, Honolulu, USA, 1-5, December 2009.

[8] Castillo-Salazar JA, Landa-Silva D, Qu R. "Workforce Scheduling and routing problems: literature survey and computational study". Annals of Operations Research, 239(1), 39-67, 2016.

[9] Cheng E, Rich JL. "A Home Health Care Routing and Scheduling Problem". Department of Computational and Applied Mathematics, Rice University, Texas, USA, Scientific Report, 1998.

[10] Cordeau JF, Laporte G, Pasin F, Ropke S. "Scheduling technicians and tasks in a telecomunication company". Journal of Scheduling. 13(4), 393-409, 1998.

[11] Pinedo ML. Scheduling Theory, Agorithms and Systems. $6^{\text {th }}$ ed. New York, USA, Prentice Hall, 2016.

[12] Pinedo ML. Planning and Scheduling in Manufacturing and Services. $2^{\text {nd }}$ ed. New York, USA, Springer, 2009. 